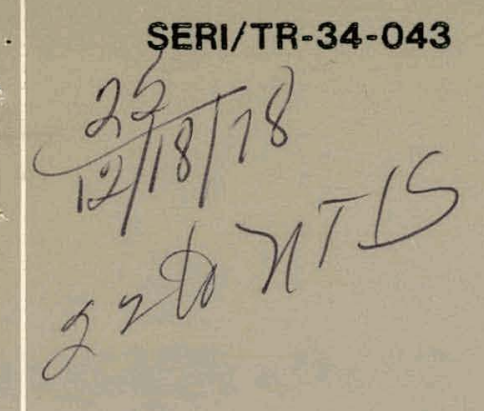

August 1978

Department of Energy

Contract No. EG-77.C.01-4042

\title{
STAM
}

\section{SERI Standard Module For Collector Evaluation}
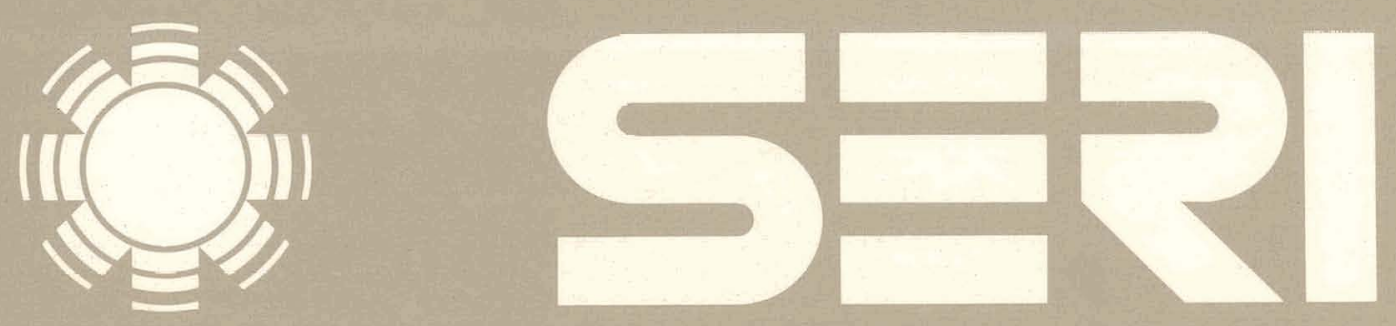

Jim Castle

\section{Solar Energy Research Institute}




\section{DISCLAIMER}

This report was prepared as an account of work sponsored by an agency of the United States Government. Neither the United States Government nor any agency Thereof, nor any of their employees, makes any warranty, express or implied, or assumes any legal liability or responsibility for the accuracy, completeness, or usefulness of any information, apparatus, product, or process disclosed, or represents that its use would not infringe privately owned rights. Reference herein to any specific commercial product, process, or service by trade name, trademark, manufacturer, or otherwise does not necessarily constitute or imply its endorsement, recommendation, or favoring by the United States Government or any agency thereof. The views and opinions of authors expressed herein do not necessarily state or reflect those of the United States Government or any agency thereof. 


\section{DISCLAIMER}

Portions of this document may be illegible in electronic image products. Images are produced from the best available original document. 


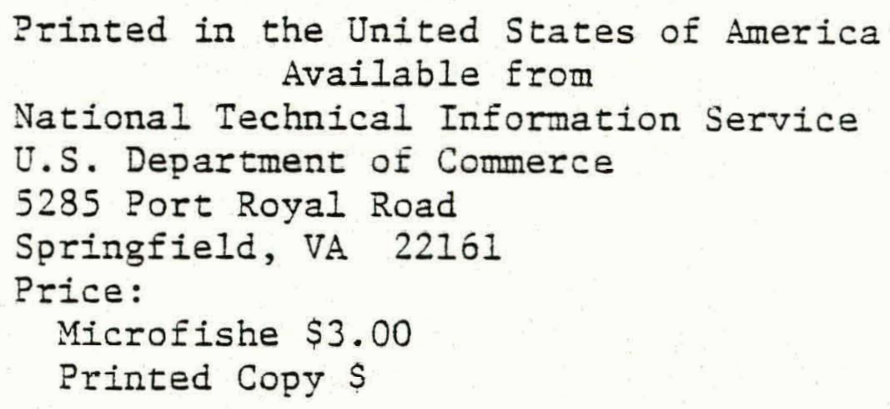

This report was prepared as an account of work sponsored by the United States Government. Neither the United States nor the United States Department of Energy, nor any of their employees, nor any of their contractors, subcontractors, or their employees, makes any warranty, express or implied, or assumes any legal liability or responsibility for the accuracy, completeness or usefulness of any information, apparatus, product or process disclosed, or represents that its use would not infringe privately owned rights. 
SERI /TR-34-043

UC CATEGORY: UC-59C

STAM

SERI STANDARD MODULE

FOR COLLECTOR EVALUATION

AUGUST 1978

JiM CASTLE

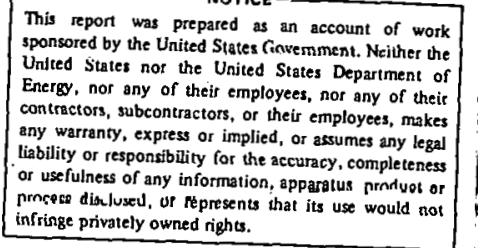

\section{Solar Energy Research Institute}

1536 Cole Boulevard

Golden, Colorado 80401

A Division of Midwest Research Institute

Prepared for the

U.S. Department of Energy

Division of Solar Technology

Under Contract EG-77-C-01-4042 


\section{PREFACE}

This document describes the steps being followed in the development of the STAM (STAndard Module) facility at the Solar Energy Research Institute. STAM is a versatile collector test module that will be used to facilitate development of a standard testing procedure for evaluating the thermal performance of concentrating solar collectors.

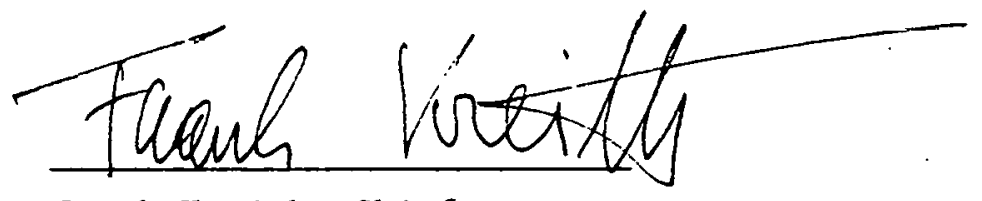

Frank Kreith, Chief

Therma1 Conversion Branch

Approved for:

SOLAR ENERGY RESEARCH INSTITUTE

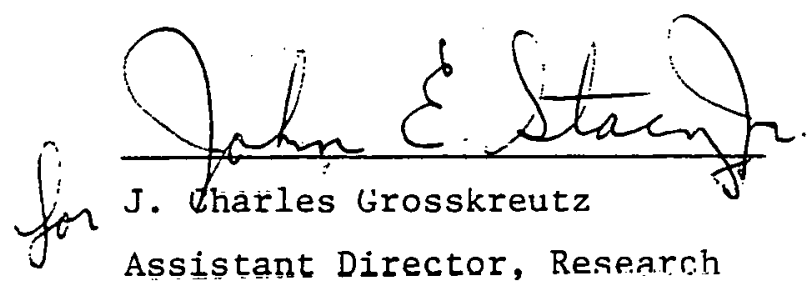


1.0

Introduction . . . . . . . . . . . . . . 1

2.0

Research Needs to Be Satisfied

2

3.0

Module Capabilities . . . . . . . .

4

4.0

Calorimetric Ratio Technique . . . . .

8

5.0

Procurement . . . . . . . . . . . .

9

6.0

SERI Field Site .. . . . . . . . . . .

10

7.0

Implementation . . . . . . . . . . .

12

8.0

Use Schedule . . . . . . . . . . .

14

9.0

Module Manpower Support . . . . . . . .

Appendix A Module Procurement Specification

\section{LIST OF FIGURES}

Figure

Page

1 Module Schematic . . . . . . . . .

2 Arrangement of Module Test Stations,...

STAM Placement at Field Site . . . . . 


\section{ABSTRACT}

A test facility is being planned for use at the Solar Energy Research Institute (SERI). Identified as STAM (STAndard Module), the facility will be capable of supplying a working fluid under carefully controlled temperature and flowrate conditions to whatever solar collector may be connected to the facility. This capability will be useful in such areas of investigation as collector thermal performance, materials testing, and reliability studies. Initially, emphasis will fall on using the facility to evolve a standard testing procedure for quantifying the thermal performance of concentrating solar collectors. To this end, the equipment will permit measuring the useful energy generated in a solar collector via the conventional $\dot{\mathrm{mC}}_{\mathrm{p}} \Delta \mathrm{T}$. procedure (as used in ASHRAE 93-77) as well as the calorimetric ratio technique which offers special advantages at higher operating temperatures. Implementation of the facility will occur in several stages. A detailed design is to be prepared first, based upon SERI's specification of the facility's operating characteristics. Fabrication and installation at the SERI field site will then occur in the last quarter of CY78. 
Section 1.0

INTRODUCTION

This document presents the rationale being followed in the development of an outdoor concentrating collector test module for use by the Thermal Conversion Branch at the Solar Energy Research Institute (SERI). The following sections outline first the need for such an experimental capability at SERI and then discuss the manner in which a preliminary design for the module can fulfill these requirements. The module will be a beneficial asset available to several branches within the Research Division. An implementation schedule is presented which details the incremental growth of the module, over several years, into a versatile and necessary SERI test module.

The Standard Module (STAM) can be thought of as a single unit which circulates a working fluid under controlled conditions through the receiver portion of a solar collector. This action serves to deliver of extract measurable amounts of energy at the receiver on a short- or long-term basis. 
Section 2.0

RESEARCH NEEDS TO BE SATISFIED

\begin{abstract}
A variety of experimental tasks must be accomplished to resolve specific research questions which are not fully amenable to analysis. These areas of uncertainty with respect to solar collector devices include items such as transient behavior, longterm performance changes, and component reliability. The following list identifies current needs which STAM is intended to help fulfill.
\end{abstract}

a. One of the Thermal Conversion Branch tasks is the development of a standard thermal performance testing procedure appropriate to concentrating collectors. It. is expected that the module would be able to fully implement any proposed standard. Refinements in the standard would be made based on direct experience with a variety of commercially available collectors.

b. The Materials Branch wants to compare the behavior of several surface coatings on an operating collector receiver. This could be accomplished by operating the collector via the proposed module and monitoring performance characteristics.

c. It is crucial that SERI develop a thorough knowledge of the operational characteristics of concentrating collectors because one major task of the Thermal. Conversion Branch is designed to identify midtemperature solar applications (100-300C) which can be met by concentrating collectors. The proposed module represents a first-step capability for developing this experience. Moreover, the experience gained with this simple module can be used directly in planning experiments for industrial process heat applications. 
d. Long-term performance data are needed to evaluate concentrating collectors. The proposed module is being planned so that a portion of the circulating fluid can be specially conditioned and devoted to maintaining a collector operational on a long-term basis. With close attention to the long-term stability of instrumental calibration it will be possible to quantify performance changes with time.

e. The proposed module can serve as a test bed where advanced receiver modules $c$ an be developed. For example, a receiver designed for a fluid phase change during transit may be developed at SERI, and it would be a new candidate for testing.

f. The Photovoltaics Branch is considering the benefits offered by concentrating radiation onto solar cells and using waste heat. The proposed module could be utilized to study hybrid photovoltaic systems. (Simultaneous generaliun of lieat and electricity).

g. The magnitude of circumsolar radiation can impact the performance of culleclurs having a large concentration ratio. Testing can quantify the extent of this influence under real and/or simulated conditions.

STAM is not unique in its concept, though several features of its design and application are expected to be. Similar units, but with different objectives, are in operation at various industrial and laboratory sites in this country. Sandia Laboratories alone is known to have ar least three such sel-ups and is preparing to procure a fourth. This test capability may be thought of as being analogous to a spectrometer. It forms a standard test piece of equipment useful to many SERI tasks in a variety of applications. 
Section 3.0

MODULE CAPABILITIES

A schematic layout for the module has been prepared in response to the needs just outlined. A preliminary quantification of the operational characteristics is also available. The paramount features are detailed here:

a. Number of collector work stations

b. Number of stations active at any time

1 or 2

- This permits interchange of a collector module without compromising testing at other stations.

c. Maximum collector area serviceable

$400 \mathrm{ft}^{2}$

- Based on peak performance $(n=.7)$ of two collectors having $200 \mathrm{ft}^{2}$ apertures. In a heating mode (e.g., nighttime thermal loss measurements), the maximum aperture is $200 \mathrm{ft}^{2}$ (one collector module).

d. Fluid flowrate

0.2 to $10 \mathrm{gal} / \mathrm{min}$ per collector

- The maximum rate is based on a receiver tube $\Delta \mathrm{T}=$ $10 \mathrm{~F}$ under the most severe operating conditions experienced by a $200 \mathrm{ft}^{2}$ aperture collector.

e. Operating temperature range

Water

$150 \mathrm{~F}$ to $450 \mathrm{~F}$

Heat transfer fluid

$150 \mathrm{~F}$ to $650 \mathrm{~F}$

- The 650F figure is an approximate upper temperature limit that can be achieved by a fluid (nonmetallic) having a low vapor pressure and having a 
liquid state at ambient temperature (such as Therminol 66). The highest water temperature avoids large operating pressure ( $<500$ psia) and thereby reduces the cost of the pump.

f. Control provisions

- The module will initially be configured to operate in a constant collector inlet temperature and flowrate mode. This mode is most useful in quantifying thormal forformanis. finntrot. capability can be expanded in the future to permit the flowrate to vary in a continuous mode so that the collector outlet temperature also remains constant (applications oriented node).

g. Measured parameters include:

Fluid inlet temperature Mass flowrate

Pressure in receiver

Receiver pressure drop

Fluid exit temperature

Ambient temperature
Ambient wind speed, direction Wet bulb temperature Direct beam radiation Diffuse radiation Circumsolar distribution Temperature rise across heater

Figures 1 and 2 illustrate the conceptual layout of STAM. Data acquisition would be coordinated with the central data system to be provided and maintained by the Test and Measurement's Group. A real-time, visual display of critical paramaters will be required via CRT or digital panel meters at the test site. 'lhe data acquisition computer may also be called upon to exercise the fluid flow control function based on observed fluid temperatures. 


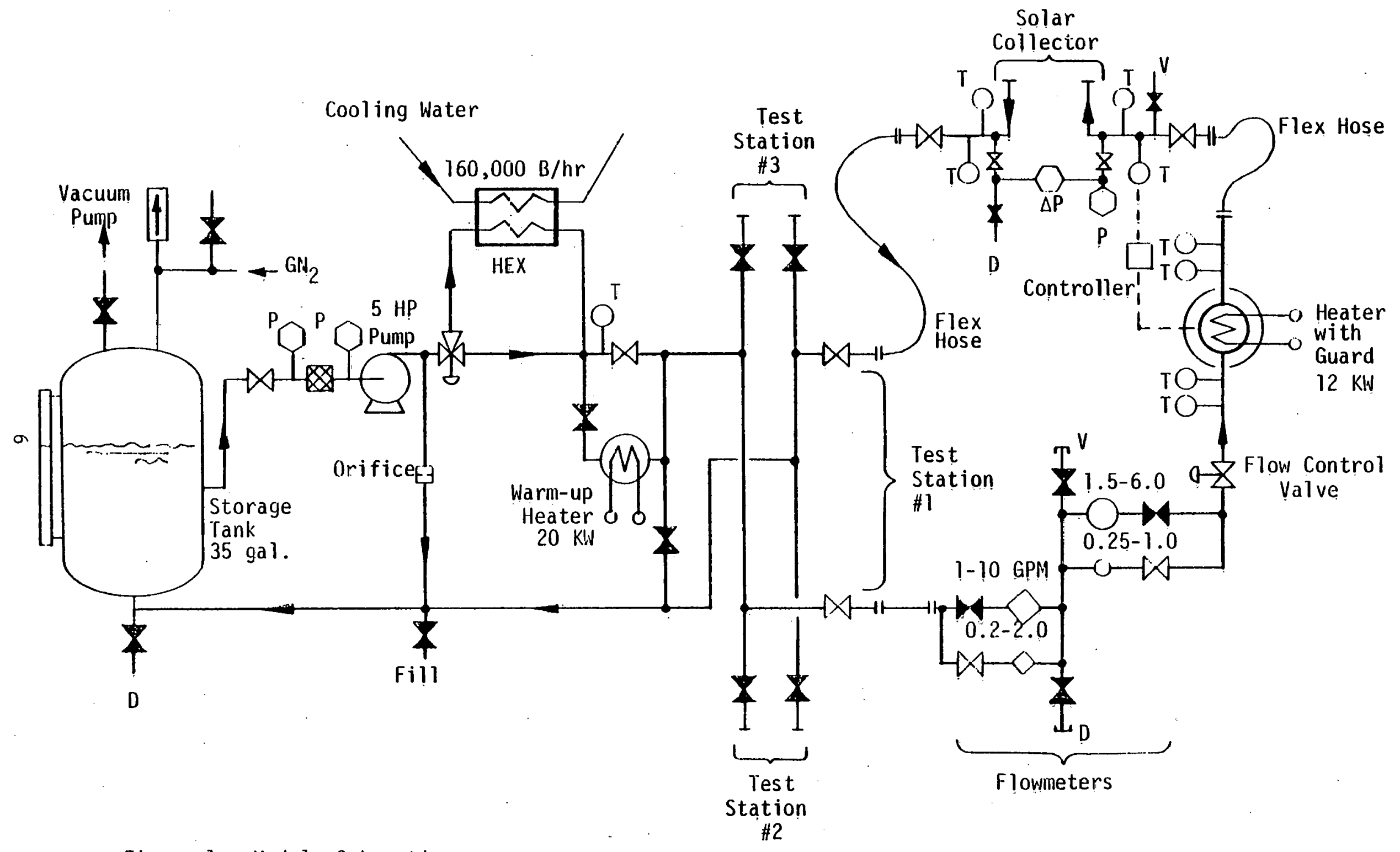

Figure 1. Module Schematic 


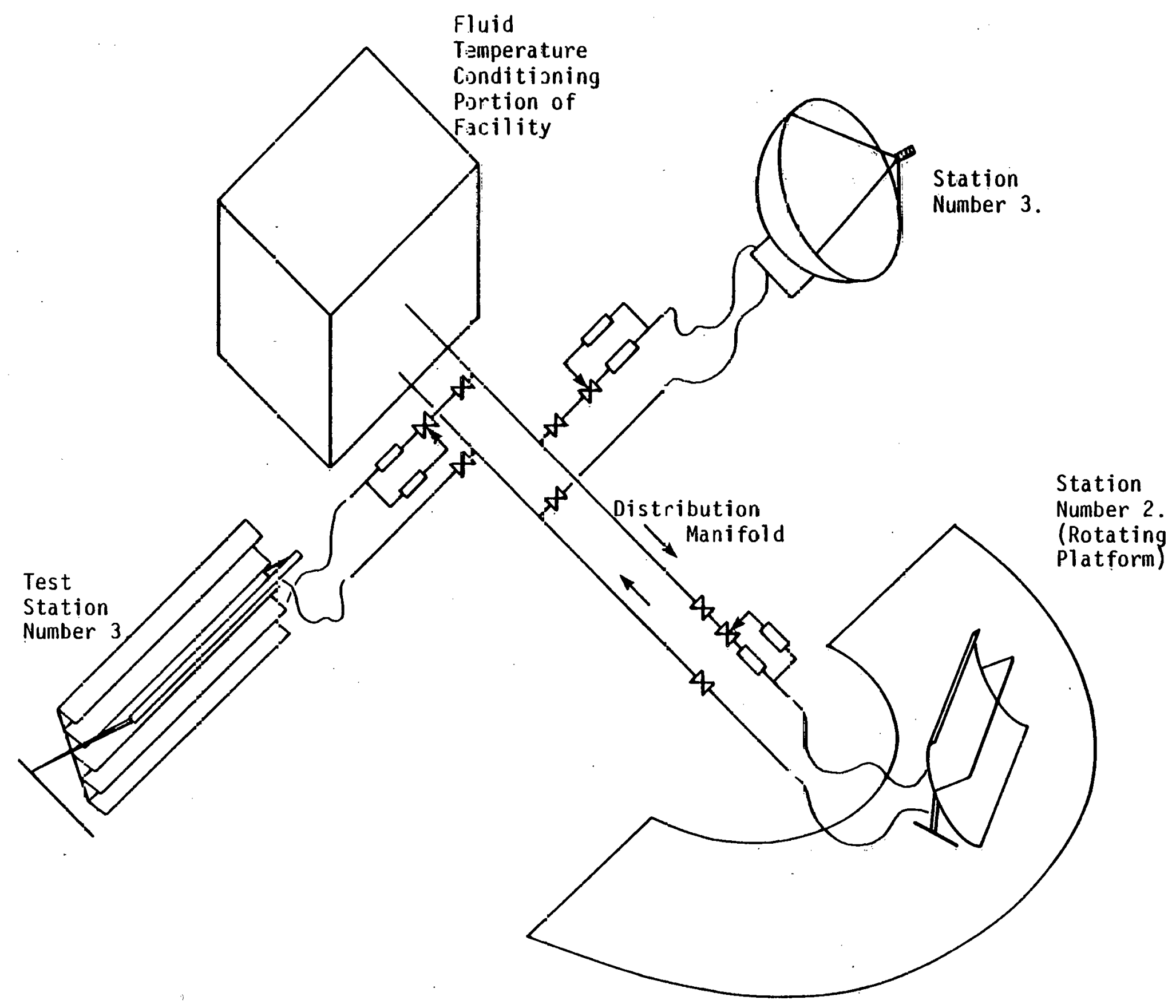

Figure 2. Arrangement of Mocule Test Stations 
Section 4.0

CALORIMETRIC RATIO TECHNIQUE

The STAM design will incorporate redundancy with respect to parameters critical in evaluating collector thermal performance. Dual flowmeters of different generic types will be present, as will multiple thermowells at critical temperature sensing locations. These measurements, however, are input to a single technique for measuring performance. This approach relies upon calculating $\dot{m} C_{p} \Delta T$ as an indication of the incident solar energy transferred to the working fluid. Two specific weaknesses in this approach are:

a. The uncertainty in flowrate measurements at high temperature based on low-temperature calibrations, and

b. The uncertainty in the magnitude of the fluid specific heat for the fluid batch being used.

The Calorimetric Ratio technique can also be implemented as a separate and redundant performance evaluation technique that is not limited by the two uncertainties listed. This technique involves heating the fluid upstream of the collector using a measured electric power input. The fluid temperature rise through the resistance heater is then measured, as well as that taking place in the collector itself. The enthalpy rise in the collector (equivalent to $\dot{m} C_{p} \Delta T$ ) is the heater power multiplied by the ratio of $\Delta \mathrm{T}$ in the collector to $\Delta \mathrm{T}$ in the heater. Minor corrections can be made for small changes in fluid specific heat between the heater and the collector.

The Calorimetric Ratio technique appears to be a viable procedure for evaluating thermal performance. A critical assessment of this approach should be made by SERI as part of its plan to develop a. concentrating collector thermal performance standard. 
Section 5.0

PROCUREMENT

A specification has been prepared in order to solicit detailed design services for the Concentrator Module. Stone and Webster Engineering has been selected to prepare the design according to SERI's specifications and estimate the total fabrication costs. Subsequently, bids will be requested from firms prepared to fabricate in conformance with the resulting design. Costs will be more clearly defined at the completion of the design phase. At this time a rough breakdown in expenses is:

$\begin{array}{lc}\text { Prepare detailed design } & \$ 20 \mathrm{~K} \\ \text { Fabricate facility } & 50 \\ \text { Prepare test. pad } & 10 \\ & \$ 80 \mathrm{~K}\end{array}$

A copy of the module specification document $c$ an be found in Appendix A. Funding has been provided in the FY78 Annual Operating Plan. 
Section 6.0

SERI FIELD SITE

STAM will be one of the first facilities erected at the SERI interim field site. Figure 3 depicts the physical layout at the field site. The facilities are clustered about a support building which houses the data acquisition equipment, mechanical, and electrical support facilities. The building serves as an operating base for technicians working at the site. STAM is positioned directly north of the support building and is placed such that no shadowing of collectors under test will occur. Underground utilities and instrument cable conduits will be used, and a meteorological tower will be nearby. Radiation instrumentation will include a pyranometer (possibly shaded, depending upon type of collector present) and pyrheliometer. It is expected that the Berkeley scanning circumsolar telescope will also be present at the field site.

Figure 3 also indicates the location of the field site on the north side of the route $I-70$. This location is within one mile of planned SERI laboratory building 8 and is accessed via the Gladiola freeway overpass. 

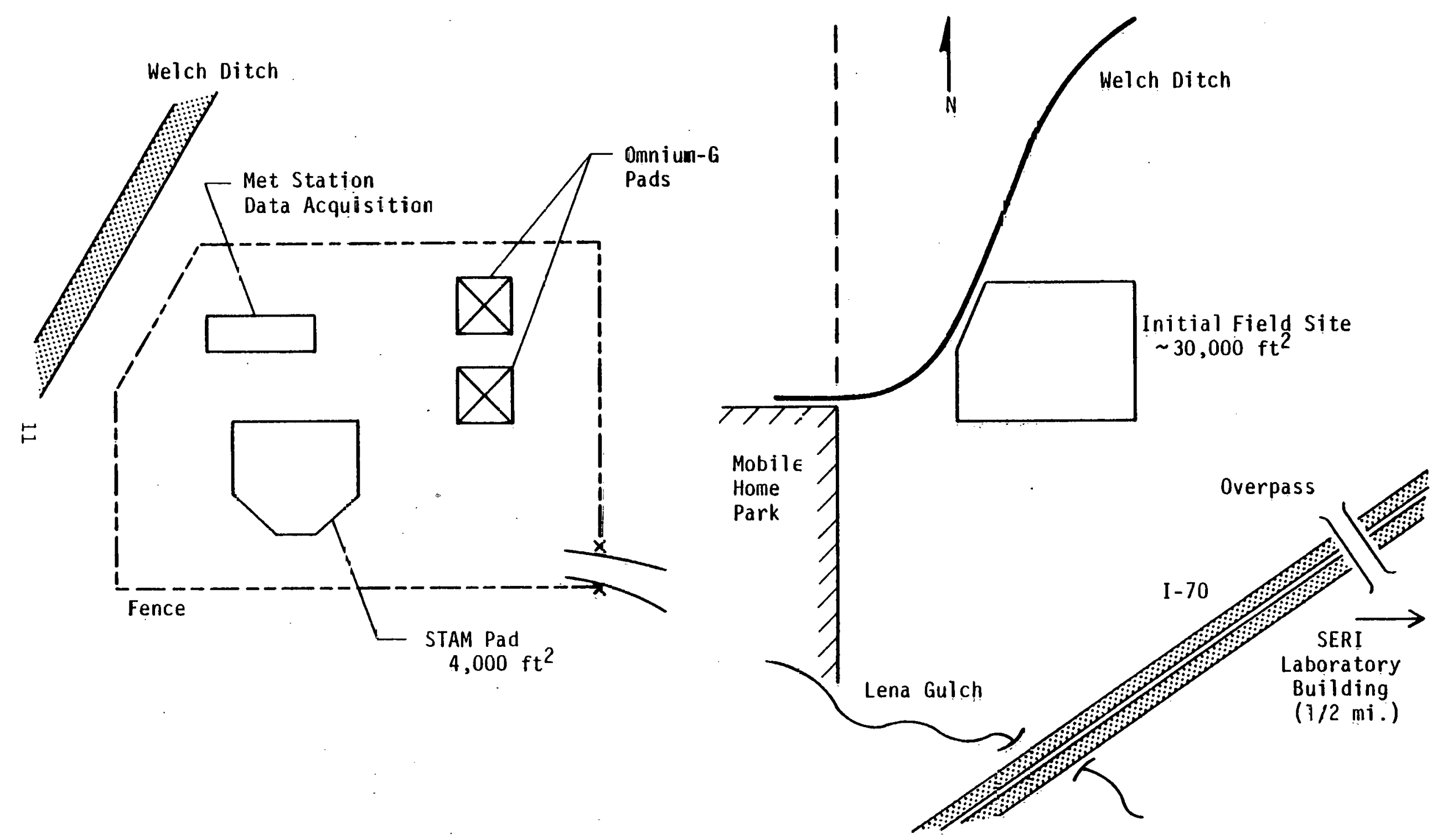

Figure 3A. STAM Placement at Field Site

Figure 3B. Field Site Location 
Section 7.0

IMPLEMENTATION

SERI personnel are actively working toward implementation of the Concentrator Module. Figure 4 describes the sequential manner in which the module could achieve fruition if action is taken promptly. The schedule shows that it should be possible to have an operational system available in the first quarter of FY79. During the following year several augmentations to the module may be considered. First to be considered is the addition of a rotating platform on which collectors can be mounted in order to enhance their tracking capability. Such a feature provides dividends in terms of being able to operate a collector with a constant solar incidence angle throughout the day. Secondly, by augmenting the module's heating and heat rejection capability, a portion of the fluid stream can be dedicated to long-term performance testing. 
Solicit Bids for Detailed Design

Detailed Design Preparation

Solici: Fabrication Bids

Fabricate Facility Module

Prepare Test Site

セ

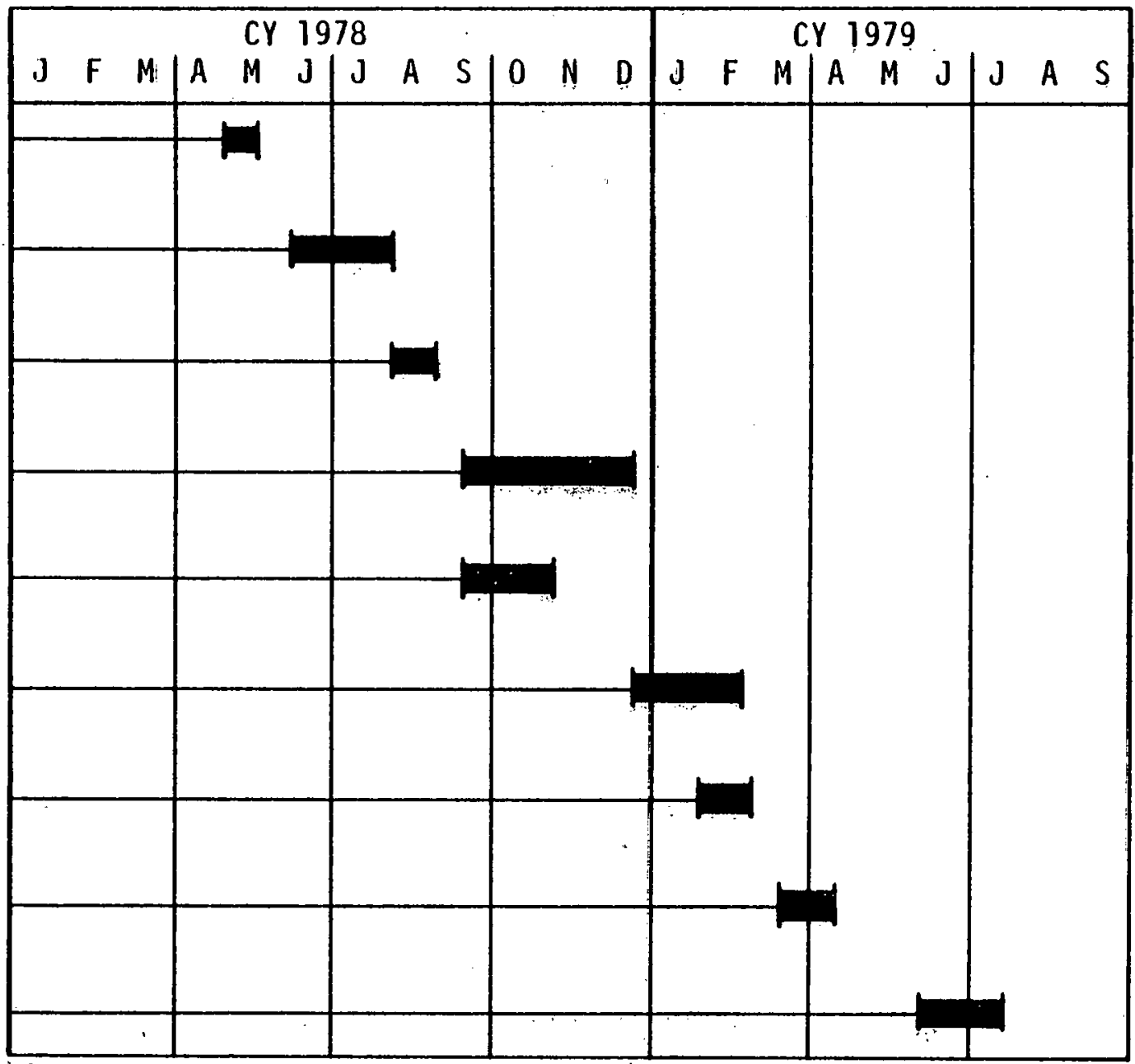

Figure 4. Concentrator Performance Standard Test Module Implementation Schedule 
Section 8.0

USE SCHEDULE

The sequence in which testing would take place at the STAM is in a conceptual stage only at this time. Section 2.0 outlined various needs which could be serviced by the module. Figure 5 illustrates a three-year time plan as to how these goals might be met. A well-defined schedule must wait on the formation of distinct task objectives in all areas. 
Collector performance:

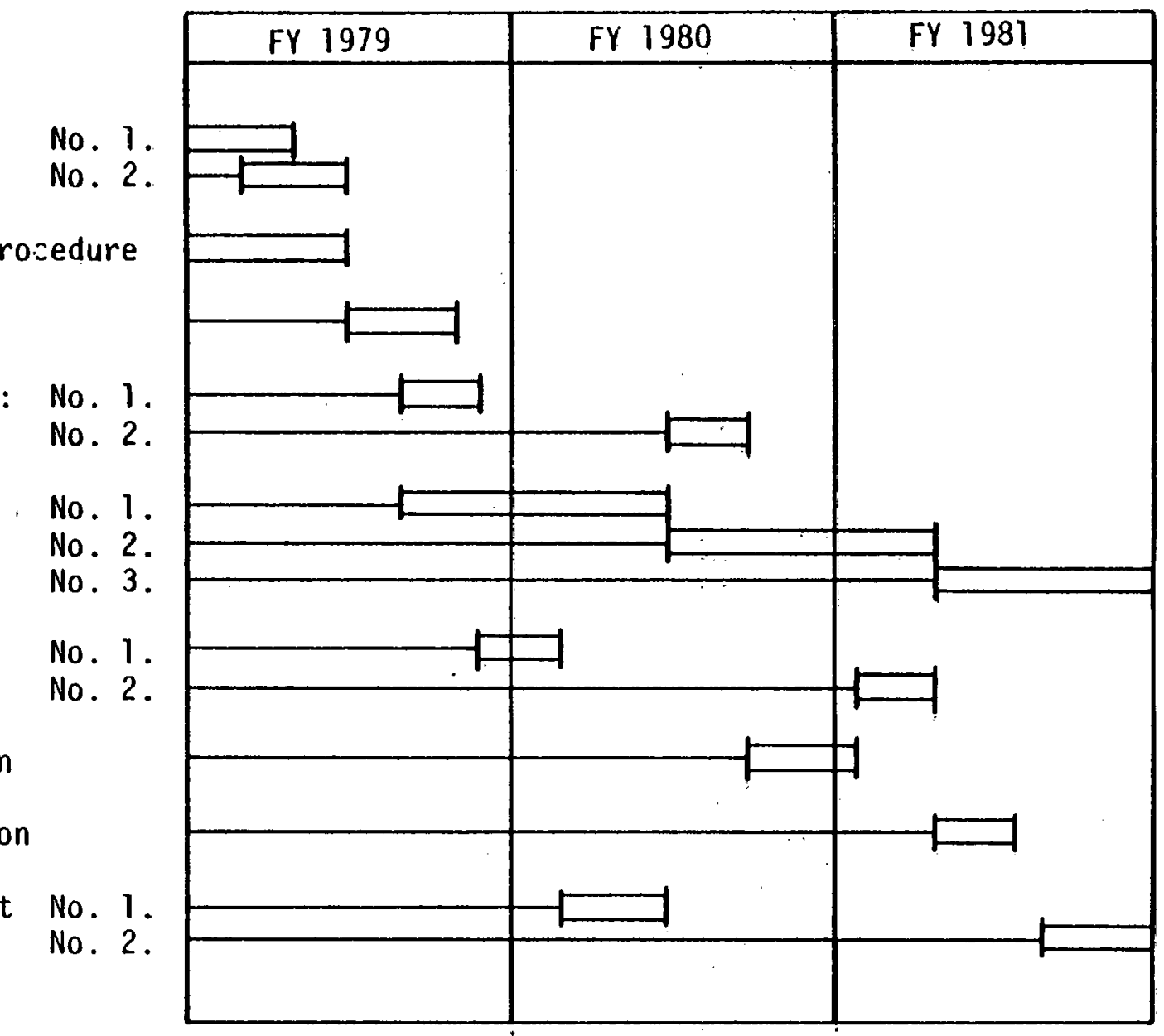

Figure 5. Preliminary Use Schedule 
Section 9.0 .

MODULE MANPOWER SUPPORT

A single full-time, mechanical technician should be capable of carrying out individual collector tests using the module. He would be assisted on a part-time basis by a second technician during installation and removal of collector modules and during testing startup and shut down. Data acquisition support from the Test and Measurements Group would also be required. Facility supervision would be exercised by a Test Engineer on a part-time basis. This individual would be responsible for data interpretation and test report preparation. Additional support would be necessary with regard to instrumentation calibration, machine shop services, central data acquisition, and procurement. 
APPENDIX A

Module Procurement Specification

1.0 SCOPE

This document identifies the operational and physical characteristics of a fluid Test Loop Module (TLM) to be designed for the Solar Energy Research Institute (SERI). The TLM, to be located in Golden, Colorado, will be used by SERI to impose a variety of test. conditions (selected fluid flowrates and temperatures) on candidate: solar collectors. It shall be possible to test a single collector or two collectors simultaneously. The Contractor shall be responsible for the complete detailed design of the TLM and shall estimate the cost of its construction per a schedule mutually determined between the contractor and SERI.

\subsection{TEST LOOP MODULE (TLM) DESIGN CONDITIONS}

\subsection{FACILITY SCHEMATIC}

The TLM shall be designed to deliver a fluid (water or heat transfer fluid) under controlled conditions to the Absorber Tube Units (ATU's) of solar collectors. The TLM shall be designed to be connected to as many as three solar collectors, any one or two of which may be under test at a given time. The ATU is that portion. of the collector in which some fraction of the incident solar energy (a variable input) is extracted in the form of a heated fluid. The TLM shall incorporate the following major components :

- Fluid storage tank ( 25 gal.)

- Circulating pump

- Fluid heater

- Heat dissipation unit

- Flowme ters

- Pressurization, vent, and relief system 
- Sensors for data acquisition

- Temperature controller

- Flexible lines for connecting the TLM to the ATU

Attachment A contains several schematics as an illustration which describe arrangements of these components which may be capable of fulfilling the detailed requirements to be identified in this document. The Contractor is not bound to any arrangement shown. The Contractor shall consult with and obtain SERI's approval of his proposed system schematic prior to initiating a detailed design of the TLM.

\subsection{ASSEMBLY OF THE TLM}

The major TLM components shall be attached to a single welded steel framework provided with lifting lugs and fork lift access. The TLM shall be designed for both operational and idle modes in a Denver area outdoor environment [ambient temperature -29C ( $-20 \mathrm{~F})$ to $38 \mathrm{C}(+100 \mathrm{~F})]$.

\subsection{UTILITIES AVAILABLE AT THE FIELD FACILITY}

$\begin{array}{ll}\text { City Water } & 0.32 \mathrm{~L} / \mathrm{sec}(5 \mathrm{GPM}) \text { @ } 275 \mathrm{KPa}(40 \mathrm{psig}) \\ & \text { @ } 18 \mathrm{C}(65 \mathrm{~F}) \\ \text { Drain } & 0.63 \mathrm{~L} / \mathrm{sec}(10 \mathrm{GPM}) \\ \text { Electricity } & 115 \mathrm{VAC}-1 \emptyset \quad 50 \mathrm{~A} \\ & 208 \mathrm{VAC}-3 \emptyset 100 \mathrm{~A}\end{array}$

\subsection{TLM OPERATING CONDITIONS}

Rate of fluid delivery to each ATU

$$
0.013-0.95 \mathrm{~L} / \mathrm{sec}
$$

$$
(0.2-15 \mathrm{GPM})
$$

Temperature of fluid exiting ATU

$\begin{array}{ll}\text { Water (1iquid phase) } & \leqslant 205 \mathrm{C}(400 \mathrm{~F}) \\ \text { Heat transfer fluid } & \leqslant 343 \mathrm{C}(650 \mathrm{~F}) \\ \text { (see Attachment B) } & \leqslant 5\end{array}$




$$
\begin{array}{ll}
\text { Energy gain in each ATU } & \leqslant 11.7 \mathrm{~kW}(40,000 \mathrm{Btu} / \mathrm{hr}) \\
\text { Energy loss in each ATU } & \leqslant 11.7 \mathrm{~kW}(40,000 \mathrm{Btu} / \mathrm{hr}) \\
\quad \text { (no solar input) } & \leqslant 10
\end{array}
$$

The TLM design shall accommodate the maximum solar energy gain in the ATU's of two collectors, but the energy loss of only one ATU. No tests are to be conducted with simultaneous energy gain in one collector and energy loss in a second.

\section{2..5 TRANSDUCER SENSING ACCURACY}

$$
\begin{aligned}
& \mathrm{T}_{\text {out, }} \mathrm{T}_{\text {in }} \text { - ATU fluid outlet inlet tem- } \pm 0.5 \mathrm{C}(0.9 \mathrm{~F}) \\
& \text { perature (mixing device, thermowells } \\
& \text { required) } \\
& \Delta \mathrm{T} \text { - Fluid temperature change though ATU } \pm 0.05 \mathrm{C}(0.09 \mathrm{~F}) \\
& \text { (mixing devices, thermowells required) } \\
& P_{\text {in }} \text { - ATU fluid inlet pressure } \quad \pm 2 \% \text { (absolute) } \\
& \Delta \mathrm{P} \text { - Pressure drop through ATU } \quad \pm 690 \mathrm{~Pa} \text { (0.1 psid) } \\
& \text { [ } \leqslant 137 \mathrm{KPa} \text { (20 psid]. } \\
& \dot{m} \text { - ATU mass flowrate } \pm 1 \% \\
& \text { (redundant instruments required) }
\end{aligned}
$$

Signal levels (for data acquisition) shall be $4-20$ ma.

\subsection{FLOWRATE CONTROL}

ATU flowrate control shall be accomplished manually [throttle valve(s)] or by pump speed control (for a positive displacement pump). The control function shall be compatible with the subsequent addition of a commercially available automatic controller if so desired by SERI. 


\subsection{TEMPERATURE CONTROLLER}

It shall be possible to pre-select $[ \pm 2.8 \mathrm{C}(5 \mathrm{~F})]$ an ATU inlet temperature (within the range 65C (150F) to 343C (650F) which will be maintained $[ \pm 1 C(2 F)]$ by the controller. This control function shall be realizable for any fluid flowrate and energy input $[\leqslant 23.4 \mathrm{~kW}(80,000 \mathrm{Btu} / \mathrm{hr})]$, or energy loss $[\leqslant 11.7 \mathrm{~kW}$ $(40,000 \mathrm{Btu} / \mathrm{hr})]$. The TLM operator shall be able to readily select which of the three inlet temperature sensors will be the input to the control function.

\subsection{FILL/DRAIN}

The TLM shall have provisions for complece gravity fill and drain. The Contractor shall identify the fill and drain procedures as well as inerting provisions when dry. Vents shall be provided to assist the fill/drain process.

\subsection{ATU FLOW RESISTANCE}

The ATU flow loss characteristic shown in Attachment C shall be used for design purposes.

\subsection{FLUID HEATING}

An electrical resistance heater in the TLM shall be capable of raising the bulk temperature of the circulating fluid from $O C$ (32F) to any desired operating value within a maximum period of 150 minutes (with no energy input at the ATU). Forced convection over the heating surfaces shall be present. The heat input rate from the electrical heaters shall be selected in accordance with the manufacturer's recommendations for the heat transfer fluids under consideration to prevent chemical breakdown. 


\subsection{THERMAL INSULATION}

All of the fluid containing portions of the ATU shall be thermally isolated from ambient conditions with weather resistant insulation. Ambient temperature for design purposes shall be $4 \mathrm{C}$ (40F). Maximum rates of heat loss shall be less than $72 \mathrm{~W}$ per meter ( $75 \mathrm{Btu} / \mathrm{hr}$ per foot) of piping and flexible hose (average over total length) and $235 \mathrm{~W}$ per $\mathrm{m}^{2}\left(75 \mathrm{Btu} / \mathrm{hr}\right.$ per $\mathrm{ft}^{2}$ ) of storage tank surface. Insulation shall be selected which minimizes potential fire hazards in case of leakage of the hot heat transfer fluid.

\subsection{REDUNDANT FLOWMETERS}

A singly redundant flowrate measuring capability (series arrangement) shall be present at each of the three solar collector test stations. One of the two flowrate units shall be of the venturi type and the other, a positive displacement type. Parallel units may be required to encompass the full flowrate range.

\subsection{ACCOMMODATION OF ASSORTED ATU SIZES}

All-metal flexible hoses $6.1 \mathrm{~m}$ ( 20 feet) in length shall be provided to interface the TLM with the ATU's.

\subsection{CRITICAL PARAMETER DISPLAYS}

A visual display of the following parameters (in the appropriate engineering units) shall be present on the TLM (accuracy $\pm 5 \%$ ):

- Storage tank pressure

- Storage tank fluid temperature

- Storage tank liquid level

- Pump coolant outlet temperature (if used)

- Cold side outlet temperature at heat exchanger (if used)

- Heater current

- Heat dissipation unit outlet temperature 


\subsection{FABRICATION DRAWINGS/SPECIFICATIONS}

A complete set of the TLM construction drawings and specifications (one reproducible plus ten copies) shall be delivered to SERI at the end of the contract performance period. These shall include, but not necessarily be limited to, such items as:

- Fabrication drawings

- Transducer name, manufacture, specification sheet, and model number for major components

- Design limitations (pressure, temperature, etc.)

- Piping size and material

- Procedures required to remove pump and flowmeters for servicing

- Water treatment requirements

- Acceptance testing and inspection required

- Pertinent manufacturing and assembly standards (welding, cleaning, etc.)

- Power and water requirements with interface details

- Flushing procedure

- Estimated dry weight

- Thermal looo, heating calculations

- Pump and system head vs. flowrate characteristics

- Safety considerations

- Operating procedures

\section{4,0 SOST ESTIMATE}

An estimate shall be made of the TLM construction rnsts. The estimate shall be itemized in these categories with material, labor, and overhead costs separately identified: 
- Pump and driver with spare parts

- Transducers/signal conditioning

- Control valves

- Temperature based controller and actuator

- Storage tank

- Resistance heater

- Heat dissipation unit

- Piping and insulation

- Site preparation

- Elecrical wiring:

- Mounting framework

- Other items

Long lead time ( $>6$ wks.) procurement items should be identified. Attachment $D$ shows the format to be used in submitting this material.

\subsection{CONSULTING SERVICES}

The Contractor may not be involved in either or both of the subsequent construction bidding and construction phases which SERI intends to fund. In that event, the Contractor's expertise will be solicited on an hourly basis to consult on the bidding evaluation process and construction supervision.

\subsection{SERI LIAISON}

Technical coordination at SERI shall be with Jim Castle (234-7239).

\subsection{CONTRACT PERFORMANCE PERIOD}

The detailed TLM design shall be completed and submitted for approval by SERI within forty-five (45) calendar days following contract initiation. Revisions per SERI directives shall be incorporated and final documentation submitted within fifteen (15) calendar days following return of the detailed design drawings to the Contractor. 


\subsection{PROPOSAL MATERIAL TO BE SUBMITTED}

The following proposal material shall be submitted:

- Related design/fabrication experience

- Estimated labor hours and classification

- Total cost

- Identification of the cognizant engineer

- Exceptions taken to this document

- Performance schedule showing milestones and interface points with SERI

- Hourly charge rate for consulting work per Section 5.0 

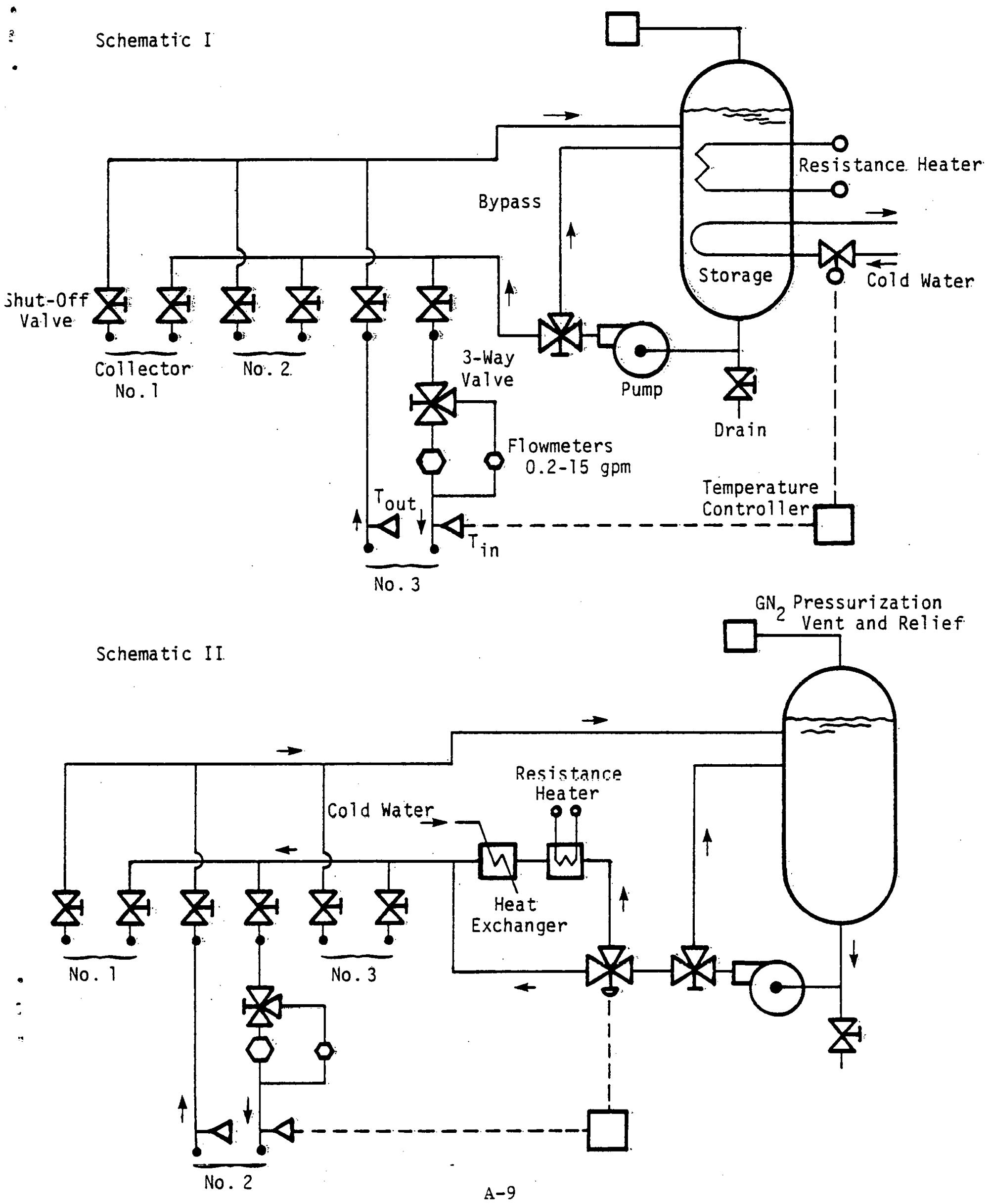


\section{ATTACHMENT $\underline{B}$}

\section{FLUID PROPERTIES}

$\rho \mathrm{kg} / \mathrm{m}^{3}$

$\left(\mathrm{ibm} / \mathrm{ft}^{3}\right)$

k W/m-C

(BTU/hr-F-ft)

$c_{\mu} \begin{array}{ll}\mathrm{kJ} / \mathrm{kg} \mathrm{C} \\ (\mathrm{RTII} / \mathrm{lbm}-\mathrm{F})\end{array}$

$\mu c p$.

( $\mathrm{lbm} / \mathrm{ft}-\mathrm{hr})$

$\mathrm{p} \mathrm{kPa}$

(psia)

WATER

\begin{tabular}{cccc}
$10 \mathrm{C}$ & 66 & 121 & 177 \\
$(50 \mathrm{~F})$ & $(150)$ & $(250)$ & $(350)$ \\
\hline 990 & 980 & 940 & 900 \\
$(62)$ & $(61)$ & $(59)$ & $(56)$
\end{tabular}

$\begin{array}{llll}.57 & .66 & .69 & .67 \\ (.33) & (.38) & (.40) & (.39)\end{array}$

4.2

4.2

$4 . ?$

4.6 .

(1.0)

(1.0)

$(1.0)$.

(1.1)

1.3

$(1.1)$

$(.23)$

.16

(3.2)

$(1.1)$

1.2

26

$(.18)$

(3.7)

200

(29)

924
$(134)$

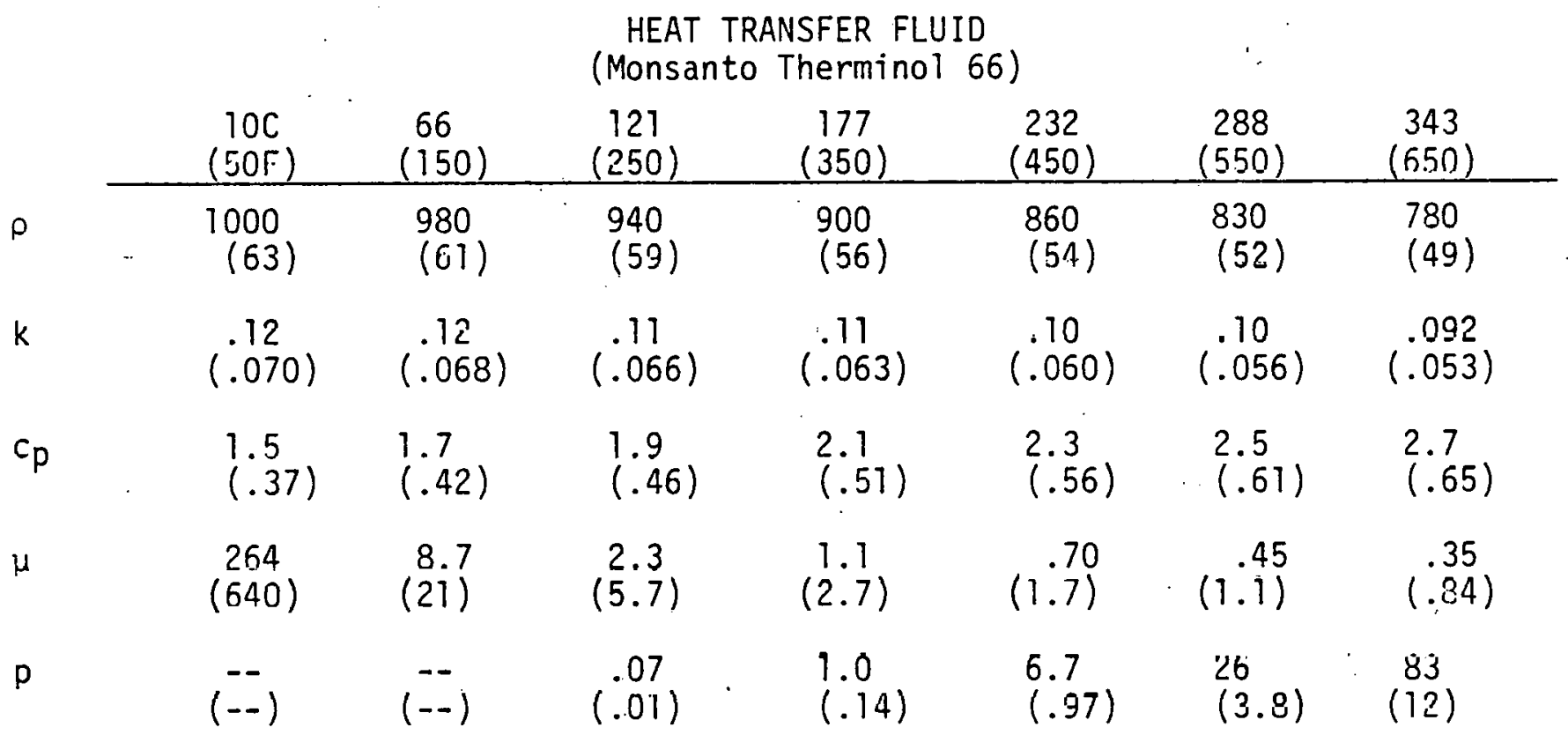

$$
\left[\begin{array}{ll}
\rho & 1.01 \mathrm{bm} / \mathrm{ft}^{3}=16.02 \mathrm{~kg} / \mathrm{m}^{3} \\
\mathrm{k} & 1.0 \mathrm{BTU} / \mathrm{hr}-\mathrm{ft}-\mathrm{F}=1.730 \mathrm{~W} / \mathrm{m}-\mathrm{C} \\
\mathrm{cp} & 1.0 \mathrm{BTU} / 1 \mathrm{bm}-\mathrm{F}=4.182 \mathrm{~kJ} / \mathrm{kg}-\mathrm{C} \\
\mu & 1.01 \mathrm{bm} / \mathrm{ft}-\mathrm{hr}=0.413 \mathrm{cp} . \\
\mathrm{p} & 1.0 \mathrm{psia}=6.894 \mathrm{kPa}
\end{array}\right]
$$


ATTACHMENT C

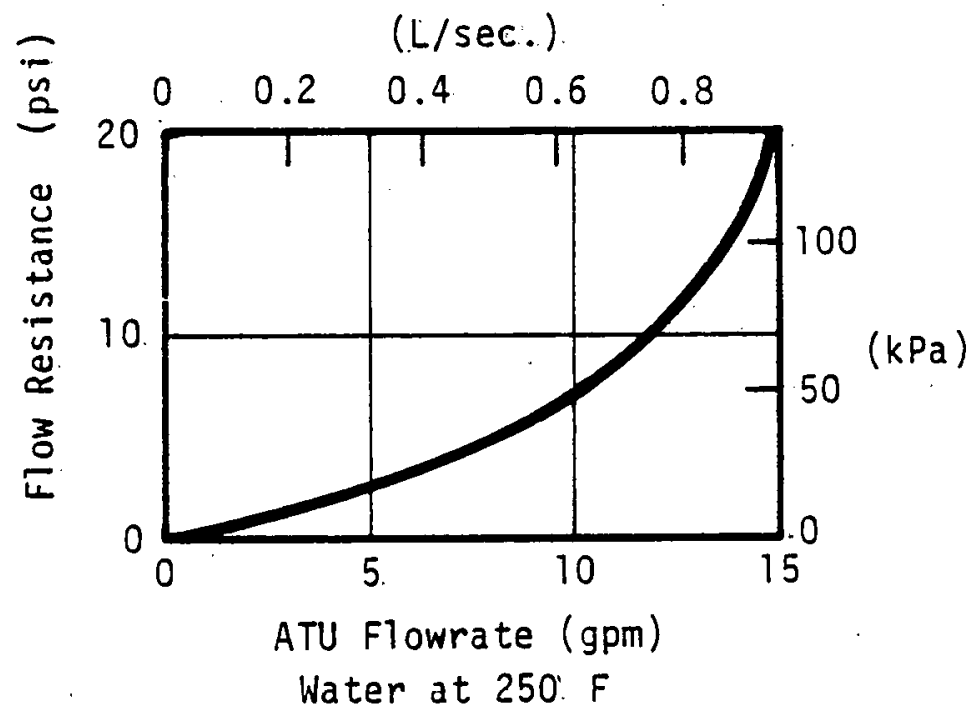


ATTACHMENT $\underline{D}$

CONSTRUCTION COST ESTIMATE

1. Pump

2. Transducers

3. Signal Conditioning

4. Control Valves

5. Controller/Actuators

6. Storage Tank

7. Resistance Heater

8. Heat Dissipation Unit

9. Piping/Insulation

10. Site Preparation

11. Electrical Wiring

12. Framework

13. Other Items

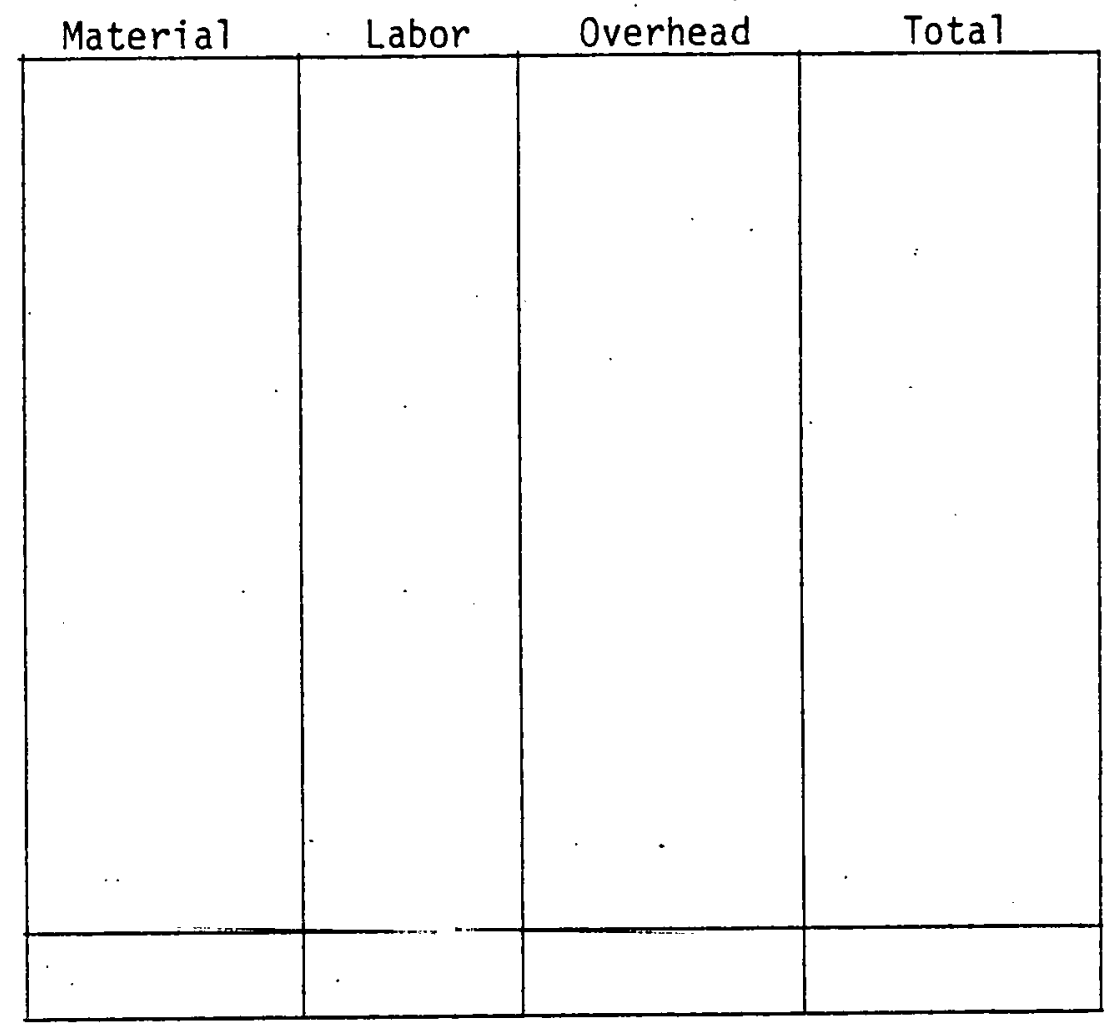

TOTAL 
No. of Copies

7

1

1

2

1

1

1.
Distribution

Department of Energy

Office of Asst. Secretary

for Energy Technology

SERI Program Office

Attn:: D.. B. Kornreich

Division of Solar Technology

office of Asst. Dir. for

Administration

Attn: R. H. Annan

Office of Procurement

Operations

Attn: Contracting officer

Office of Asst. Secretary for Conservation and Solar Applications

Attn: Ron Scott

On-site Representative

Attn: W. R. Cherry

Office of Asst. Dir. for

Thermal Power Systems

Attn: M. Gutstein

Office of Asst. Dir. for

Heating and Cooling

Attn: F. H. Morse 